\title{
The growth crisis or the twilight of world culture?
}

\author{
Andrey Y. Bolshunov ${ }^{1 *}$ and Aleksandr G. Tiurikov ${ }^{1}$ \\ ${ }^{1}$ Financial University under the Government of the Russian Federation, Department of Sociology, \\ Faculty of Social Sciences and Mass Communications, Moscow, Russia
}

\begin{abstract}
The article discusses the consequences for the culture of the priority of the rights over culture, declared by various minorities. The authors justify the thesis that this is a challenge that creates threats to the existence of culture, being an anthropotechnical experiment, whose consequences cannot be predicted due to the limited knowledge of how society functions. The authors call for searching solutions that would not lead to cultural discrimination of the majority while taking into account the rights of minorities.
\end{abstract}

Keywords: culture, world culture, planetary lifeworld, minority rights, challenges to world culture.

Following E. Husserl's definition, culture is understood as "intersubjectively constituted" lifeworld, which should be thought of as "creating of the semantic form", "semantic gestalt", "unity of spiritual form", and "universal spiritual acquisition" [1: 455; 2: 169]. Mere, culture is a pantheon of embodiment [3] constituting the lifeworld of semantic formations - a sociocultural model of humanity, symbols, and meaningful events for the inhabitants of a particular lifeworld various life situations. A specific form of production of such sociocultural models, symbols, and the rest are practices and institutions of spirituality, whose essence is formulated by Michel Foucault in the form of the "spirituality postulate": "the verity is never given to the subject for nothing"; a human, "as he is, is not capable of verity", "cannot come to the verity and does not even have the right to claim it" [4: 28]; to gain access to the verity (as, indeed, to truth, perfection, true good), a human being must change - the verity is given "only at the cost of involving the subject into the game", i.e., at the cost of acquiring subjectivity [4: 28]. Husserl emphasizes that "the accessibility [of culture] is not unconditional at all" [2: 169]. Culture brings a vertical dimension to the world, "it has inherited the hierarchical character of the cult" [5:270]. The spirituality practices and institutions function according to the principle of "many are called [more precisely, all are called - the authors' note)] but few are chosen" [3]. Such character explains the thesis of C. Geertz: "We are, in sum, incomplete or unfinished animals who complete or finish ourselves through culture - and not through culture in general but through highly particular forms of it: Dobuan and Javanese, Hopi and Italian" [5: 32]. Culture consists precisely in finding oneself by people, each individually, and represents the "path of the soul to itself" [6: 446], that is, to being a human.

\footnotetext{
* Corresponding author: aybolshunov@,fa.ru
} 
Historically, cultures and lifeworlds were local in nature. They were ethnically, and later, confessionally limited. But since the Renaissance, one has seen the formation of a planetary lifeworld and, consequently, a world culture. A pantheon of universal sociocultural models of humanity was formed in science, music, literature, arts, and the cultural sector in general. In science, for example, these were Copernicus, Galileo, Einstein, and others., in classical music - Bach, Beethoven, Mozart, Shostakovich. Einstein called himself a man of the world, and his lifeworld was the Universe, which is why he was convinced that it should satisfy the claims of his Taste, Conscience, Reason, and Common Sense. This Einsteinian selfdetermination is more or less characteristic of all the universal planetary models of humanity (after all, all of them, like Bach, according to their convictions, were in their creativity in a relationship with God, according to Kierkegaard, in absolute relation of the singular with the absolute. Not only models were formed, but also meaning-oriented events and symbols of general planetary significance (as examples, one can point to the Holocaust and the Nuremberg trials). All this was perceived, in the words of Husserl, as spiritual achievements forming a general planetary culture, a culture of high spiritual achievements of humanity that have universal significance. Giordano Bruno found in the background of this process "heroic enthusiasm", referring to the creators of ancient Greek culture - a Greek hero. This is a culture in which intersubjectivity is represented by an exposition of "geniuses" and their spiritual achievements, which have a universal (all-human) significance and meaningorienting character for people living in all corners of the world, regardless of their national or any other affiliation. An example of such an exposition is the 200-volume "Library of World Literature" published in the USSR in 1967-1997, which was very popular, and served for people the means to join the world culture. This library discovered for people the space of universality, based on the highest achievements of human genius in the arts. Here the nationality of the authors was of secondary importance since it was precisely the world literature, rather than French, German, or Russian. It was a feeling akin to "Russian cosmism" or Einstein's universe. Due to such projects, millions of Soviet citizens had a strong consciousness of world culture (despite the lack of the Internet, the presence of the Iron Curtain, etc.). Indeed, the volumes of this library were in incredible demand: they were instantly bought up, asked to read, etc. The paradox is that the consciousness of the inhabitants of the USSR was much more worldwide than the consciousness of today's generations. And this was not only in the USSR. Thus, for example, Borges, in his essays and short stories, writes often about the "world library", Eco Umberto and others reflect about the same. Examples of the latest "hero" of world culture are Gagarin and the American astronauts, the first to land on the Moon. Today it is difficult to imagine with what enthusiasm millions of people around the world greeted Gagarin.

World culture is defined as a synthesis of the best achievements of all national cultures. However, the term "synthesis" does not reflect the root of the matter. It is believed that world culture has two fundamental differences from local cultures.

First, it is a culture of production of "the leading humanistic concepts" (Gadamer) or forms of the universality of consciousness (Hegel), which are reason, conscience, taste, and common sense.

Secondly, in the world culture, the role of spiritual practices, which previously had a mystery, esoteric, mystical, religious character, is played by science and high art.

At that, the world culture and the planetary lifeworld constituted by this culture, should not be confused with globalization whose driving force is the expansion of networks (F. Braudel, and especially P. Sloterdijk [7])by the expansion of the network mode of people's existence $[8,9]$. Networks led everywhere to the collapse of local ontologies (lifeworlds), eliminated the very fact of the existence of borders (areas, spheres, outlined by the boundaries of spaces). World culture creates a planetary lifeworld. 
An alternative to the high achievement culture ("geniuses") was a mass culture, whose pantheon consists of "stars" (according to J.R. Saul [10], the first star was Napoleon). But mass culture became a competitor to the high spiritual achievement culture only in the 20th century. The main feature of mass culture is the collapse of the vertical dimension since it cannot be said that this culture is not available to everyone. Any person regardless of intellectual and cultural level can be involved in this culture. Therefore, from the standpoint of the high achievements culture, this is an anti-culture.

But the crisis of the high spiritual achievement culture is related not to mass culture. Something other happens in the first half of the 21 st century. In 2014, Biden stated that "protecting gay rights is a defining mark of a civilized nation and must trump national cultures and social traditions" [11]. Warning against accusations of non-tolerance, it's not about sexual minorities. Biden opened Pandora's box - a reason, an ideological justification, an alibi for revising the culture in someone's private, particular interests. And today, under this pretext, a radical revision of culture is unfolding in the USA and Europe. In the USA, this is the demolition of monuments and the revision of the events of their own history; the Black Lives Matter movement has already made claims to classical music, religion, literature, and cinema. In Europe, culture has long been mixed first with some universal human values, then with human rights. At that, the fact that cultures respond differently to the question of what it means to be a human is completely ignored. As a result, cultures assume different values and different human rights. This truly Nietzschean revision of values is gradually sweeping the world. Indeed, even in Russia, they cannot find symbols that would unite all Russians except for Great Patriotic War remained. Even the figures, who undoubtedly belonged to the global pantheon (Pushkin, Dostoevsky, Chekhov, Rimsky-Korsakov, Shostakovich, etc.) cannot be all-Russian symbols, because they are entirely Russians and Jews, as well as Ukrainians. And where are the Tatars, Yakuts, Caucasian peoples? That is why small nations are fighting so hard to include their epics and monuments in the UNESCO list.

Today the society returns to cultural particularism. The spirit of universality, if not having died away, is essentially slaking. Today it is hard to believe how the men of the sixties were involved in the "dispute between physicists and lyricists", how Gagarin's first flight into space was perceived by peoples, with what enthusiasm people believed that "And On Mars There Will Be Apple Blossoms", how they adored classical music, perceiving the conservatory as a temple (even those who did not attend it).

Today we find ourselves in a situation of "extraordinary ease" in dealing with culture, participating in cultural (and hence anthropotechnical) experiments, whose consequences no one can know. This is a challenge to the existence of very culture in any form that predates the present day. The paradox is that the people barely got out of the anthropotechnical experiments of the USSR, which, as it turned out, taught it a little. Nonetheless, the USSR did not question the importance of culture, although deformed it.

Many questions arise today. What should be done about it? Is art in its present state capable of producing a worldwide spiritual achievements culture? Is science capable of this, or should one be talking about some new practices of spiritual production? Or maybe the high achievement culture supposing a vertical dimension is ready to sink into oblivion? Or is the planetary lifeworld collapsing, and humanity is returning to the multiplicity of particular lifeworlds in the era of sociocultural protectionism? Shall we find the formulas for a polycentric lifeworld?

\section{Acknowledgments}

The article is based on the results of research carried out in the frameworks of budgetary funds on the state assignment of the Financial University. 


\section{References}

1. E. Husserl, Kartezianskiye meditatsii [Cartesian meditations] (Academic Project, Moscow, 2010)

2. E. Husserl, Krizis yevropeyskikh nauk i transtsendental'naya fenomenologiya. Izbrannyye raboty [The crisis of european sciences and transcendental phenomenology: selected works] (Publishing House "Territoriya Budushchego", Moscow, 2005)

3. Ch. Durt, Th. Fuchs, Ch. Tewes (Eds.), Embodiment, enaction, and culture: Investigating the constitution of the shared world (MIT Press, Cambridge, MA, London, England, 2017)

4. M. Foucault, Germenevtika subyekta: kurs lektsiy, prochitannykh v Kollezh de Franse 1981-1982 uchebnom godu [The Hermeneutics of the subject: lectures at the Collège de France 1981-1982] (Nauka, Saint Petersburg, 2007)

5. C. Geertz, Interpretatsiya kultur [The Interpretation of cultures] (Russian Political Encyclopedia, Moscow, 2004)

6. G. Simmel, Izbrannoye. Tom 1. Filosofiya kul'tury [Selection. Volume 1. Philosophy of Culture] (Yurist, Moscow, 1996)

7. P. Sloterdijk, Sfery. Mikrosferologiya. Tom 1. Puzyri [Spheres. Microspherology. Volume I. Bubbles] (Nauka, Saint Petersburg, 2005)

8. B. Latour, An inquiry into modes of existence. an anthropology of the moderns (Harvard University Press, Cambridge, 2013)

9. B. Latour, Novogo Vremeni ne bylo. Esse po simmetrichnoy antropologii [We Have Never Been Modern. Essays on Symmetrical Anthropology] (Publishing House of the European University at St. Petersburg, Saint Petersburg, 2006)

10. J.R. Saul, Ublyudki Vol'tera. Diktatura razuma na Zapade [Voltaire's Bastards, The Doubter's Companion: A Dictionary of Aggressive Common Sense] (AST: Astrel, Moscow, 2007)

11. J. Kuhnhenn, Biden: gay rights take precedence over culture". AP News. (June 25, 2014). Accessed on: December 10, 2020. [Online]. Available: https://apnews.com/article/fa46dd3a8dc7423081755e9 e16b3fb34 